\title{
RELATIONSHIP BETWEEN SPIRITUAL WELL-BEING AND QUALITY OF LIFE OF UNIVERSITY X STUDENTS DURING COVID-19
}

\author{
Pamela Hendra Heng, ${ }^{1}$ Septi Lathiifah, ${ }^{2}$ Franklin Hutabarat ${ }^{3}$ \\ 12Faculty of Psychology, Universitas Tarumanagara, Jakarta Barat, Indonesia \\ ${ }^{3}$ Faculty of Religious Studies, Asia-Pacific International University, Saraburi Thailand \\ Email:pamelah@fpsi.untar.ac.id ${ }^{1}$
}

Submit: 21 May 2021 Revised: 30 November 2021 Accepted: 2 January 2022

\begin{abstract}
During the COVID-19 pandemic, many daily activities are carried out from home. Likewise, educational activities are carried out at home online. This reduces physical activity and can lead to decrease physical and spiritual health. ${ }^{1}$ The purpose of this study was to determine the relationship between spiritual well-being and quality of life in university students during the COVID-19 pandemic. Participants in this study consisted of 54 men and women with an age range of 19 years to 22 years. This research is non-experimental quantitative research with a sampling technique using purposive sampling. The measuring instrument used to measure spiritual well-being is the spiritual well-being questionnaire (SWQ) compiled by Gomez and Fisher ${ }^{2}$ and the measuring instrument for measuring the quality of life uses the Indonesian version of the WHOQOL-BREF measuring instrument, which was developed by Purba et al. ${ }^{3}$. The results showed that there was a positive relationship between spiritual well-being and quality of life in students during the COVID-19 pandemic ( $p=0.000<0.05)$, the higher the spiritual well-being of students, the higher the quality of life of students. Additional data analysis was carried out to look for different tests, based on the results of the study there were differences in quality of life-based on gender.
\end{abstract}

Keywords: spiritual well-being, qualiy of life, student, pandemic COVID-19

\section{INTRODUCTION}

In January 2020, the World Health Organization (WHO), declared that the COVID-19 pandemic was declared a world public health emergency. ${ }^{4}$ To reduce the

${ }^{1}$ Dong, Han., Zhang, Jun., \& Cirillo, Cinzia. "Exploring, understanding, and modeling the reciprocal relation between leisure and subjective well-being". Transportation Research Part A: Policy and Practice (2019). 813-824. https://doi.org/10.1016/j.tra.2019.10.009

${ }^{2}$ Gomez, Rapson., \& Fisher, John. "Spiritual Well-Being Questionnaire[Database record]". Retrieved from PsycTESTS (2003). Doi: 10.1037/t12442-000

${ }^{3}$ Purba F. D, Hunfeld J. A. M., Iskandarsyah A., Fitriana T. S., Sadarjoen, S. S., Passchier J., \& Busschbach, J. V. "Quality of life of the Indonesian general population: Test-retest reliability and population norms of the EQ-5D-5L and WHOQOL-BREF". PLoS ONE 13(5) (2018). https://doi.org/10.1371/journal.pone.0197098

${ }^{4}$ World Health Organization. "Mental Health and Psychosocial Considerations During COVID-19 Outbreak". World Health Organization (2020). 
spread of the COVID-19 virus, the Indonesian government has decided to temporarily limit public activities such as suspending classes for students and suspending worship in public places of worship. This fact can reduce the quality of spiritual well-being and social welfare. Social distancing, quarantine, and isolation are solutions given to slow the spread of the COVID-19 virus in the community. This solution suddenly changes old habits. Most people will stay at home, unless they have a need that requires leaving the house. So they feel that they cannot be as free as before and stay at home longer than usual. This results in decreased happiness and increased stress 5 .

Based on interviews conducted by two students, it is known that students feel that their spiritual well-being is disrupted during the COVID-19 pandemic. According to participant A, during the COVID-19 pandemic, worship was carried out online. He felt that the online worship atmosphere was very different from coming directly to church. Participant A admitted that during the COVID-19 pandemic he had never attended online worship because he felt uncomfortable. In addition, other activities such as MISA cannot be carried out because the church is closed. Therefore, his worship is praying together with his parents at homé6.

For participant B, worship activities are also carried out online through the church's YouTube account. according to participant B, worship conducted online provides a different atmosphere than worshiping in person at church. Worshiping online makes him less concentrated and bored and lonely because he can't meet other people and can only worship and sing in front of a computer screen, it's no different like he is doing lectures. Worshiping online can also make participant B feel lazy to worship?.

Spiritual well-being is the quality of the relationship a person has with himself, others, nature, and $\mathrm{God}^{8}$. In particular, spiritual well-being is concerned with the state or situation of spiritual well-being that is fulfilled in the form of good relationships with oneself, others, the environment and God 9 . There are four domains of spiritual well-

\footnotetext{
${ }^{5}$ Bhandari, S., Shaktawat, A. S., Patel, B., Dube, A., Kakkar, S., Tak, A., Gupta, J., \& Rankawat, G. “The sequel to COVID-19: the antithesis to life". Journal of Ideas in Health (2020). https://doi.org/10.47108/jidhealth.vol3.issspecial1.69

${ }^{6}$ (Personal Communication, 17 July 2021).

${ }^{7}$ (Personal Communication, 18 July 2021)

8 Fisher, John. "The four domains model: Connecting spirituality, health and well-being". Religions (2011). https://doi.org/10.3390/rel2010017

${ }^{9}$ Tumanggor, Raja Oloan \& Dariyo, Agoes. "Pelatihan peningkatan spiritual well-being bagi lansia di gereja HKBP Cengkareng Jakarta Barat. Sanapenmas (2019). 394-400
} 
being according to Fisher: ${ }^{10}$ (a) the personal domain, namely the relationship of a person to the meaning, purpose, and value of life. (b) the universal domain, namely the quality of the relationship between oneself and others, the relationship with morality, culture and religion which is shown through an attitude of love, forgiveness, faith, hope and belief in humanity. (c) the environmental domain, which is an attitude that is more than just physical and biological care and maintenance, therefore there is a sense of awe and wonder so that it can blend with the environment. (d) transcendental domain, namely the relationship between oneself and something beyond the human level (such as the Supreme Being, cosmic forces, transcendental reality or God), including belief, worship or worship of God.

Spiritual well-being is one of the factors that can affect a person's quality of life. Quality of life is an individual's perception of his life position, in the context of his culture and value system, in relation to his goals, expectations, standards and interests $^{11}$. According to Tonon ${ }^{12}$ quality of life is an individual's view of his life position, in the culture or value system he adheres to, related to expectations, interests, and achievements. Quality of life also discusses the level of conformity between the individual's life and his desires, how much the individual enjoys his life, and the assessment of individual aspects that are not as desired and need to be changed.

The WHOQOL Group ${ }^{13}$ explains that there are four dimensions of quality of life, which include physical, psychological, social and environmental health. The (a) physical dimension discusses a person's physical condition, namely individual daily activities, the presence or absence of dependence on certain drugs or medications, energy and perceived fatigue, mobility, pain and discomfort, sleep and rest, and the strength to work. The (b) psychological dimension discusses the individual's psychological condition concerning appearance; negative and positive feelings; self-esteem; individual spirituality/religion/belief; and the ability to think, learn, memory capacity, and concentration. The (c) dimension of social relations discusses the social relations of

\footnotetext{
${ }^{10}$ Fisher, John. "Development and application of a spiritual well-being questionnaire called SHALOM". Religions (2010). https://doi.org/10.3390/rel1010105

${ }^{11}$ The WHOQOL Group. The World Health Organization quality of life assessment (WHOQOL): Position paper from the World Health Organization. Social Science \& Medicine, 41(10) (1995), 1403-1409.

${ }^{12}$ Tonon, G. Relevance of the use of qualitative methods in the study of quality of life. Dalam G. Tonon (Eds.), Qualitative studies in quality of life: Methodology and practice. (pp. 5) (Switzerland: Springer, 2015).

${ }^{13}$ The WHOQOL Group. WHOQOL-BREF: Introduction, administration, scoring, and generic version of the assessment (Geneva: World Health Organization, 1996)
} 
individuals with other people around them. The problems of social relations that are included in this dimension are personal relations, social support, and sexual activity. The (d) environmental dimension discusses the environmental conditions in which individuals live their daily lives.

Someone who has a high level of spiritual well-being will have a high quality of life. Research by Buulolo ${ }^{14}$ on clerical students at the Indonesian Evangelical Theology School, Medan, which shows that there is a positive relationship between spiritual wellbeing and quality of life. Another study by Piraste Motlagh et al. ${ }^{15}$ states that there is a significant positive relationship between quality of life and spirituality.

The comfort of human life is one of the things that affect religious beliefs, and can strengthen the main dimensions of the individual and society, fill emotional, moral and spiritual gaps and provide peace of mind. Religious beliefs also provide a solid foundation in facing life's shortcomings and difficulties. Almighty God always supports and gives reassurance to people who make spiritual connections with universal powers. By relying on the beliefs they have, these people face complexities more easily and are less bothered by stress and difficulties that may come in the future, and they are more optimistic and have high expectations ${ }^{16}$.

Based on the above background, the researcher wanted to know how the spiritual well-being and quality of life relationship among university students during the COVID-19 pandemic.

\section{METHOD}

This study used quantitative research with non-experimental method. The type of research used is correlational, with the aim of finding out relationship between social support mediators on academic stress and self-regulated learning in junior high school students. The sampling technique used is purposive sampling. Data was obtained by distributing Google Forms questionnaires online through instant messaging.

\footnotetext{
${ }^{14}$ Buulolo, Delviana. "Quality of Life ditinjau dari Spiritual Well-Being pada Mahasiswa Kependetaan di Sekolah Tinggi Theologia Injili Indonesia Medan-Sumatera Utara" Jurnal Psikologi Universitas HKBP Nommensen 6.1 (2019): 21-27.

${ }^{15}$ Pirasteh Motlagh, A. A., Nikmanesh, Z., Liaghat, E., \& Hematian, M. The role of spirituality in feelings of suffering and quality of life in self- introduced addicts. Journal of Research and Health (2019). https://doi.org/10.29252/jrh.9.2.104

${ }^{16}$ Ali, J., Marhemat, F., Sara, J., \& Hamid, H. "The Relationship between Spiritual Well-Being and Quality of Life among Elderly People". Holistic Nursing Practice (2015). https://doi.org/10.1097/HNP.0000000000000081
} 
This research was conducted in Jakarta in January 2021. The research instruments consisted of five parts: a cover letter, informed consent, participant's personal data, spiritual well-being questionnaire and quality of life questionnaire.

The research measuring instrument used to measure spiritual well-being is the spiritual well-being questionnaire (SWQ) compiled by Gomez and Fisher ${ }^{2}$ (2003) based on the four dimensions of spiritual well-being according to Fisher8 (2010): namely, (a) personal domain , (b) universal domain, (c) environmental domain, (d) transcendental domain consisting of 20 questions. The SWQ measuring instrument uses 5 Likert scales.

In measuring the quality of life, it is measured using the Indonesian version of the WHOQOL-BREF measuring instrument, which was developed by Purba et al. ${ }^{3}$ (2018). The measuring instrument consists of 26 questions. Two of them measure the overall quality of life and the general health condition of the participants. The other 24 questions are divided into four dimensions, namely physical, psychological, social relations, and environmental dimensions. The Indonesian version of the WHOQOLBREF measuring instrument uses 5 Likert scales.

\section{RESULT AND DISCUSSION}

\section{Result}

The participants of this study are junior high school students aged 19 years old $>22$ years old. Gender, ethnicity, and religion are not limited by the author. Total participants obtained are 54 people.

Tabel 1. Participant based on Gender

\begin{tabular}{lll}
\hline Gender & Amount & Percentage (\%) \\
\hline Male & 13 & 24.1 \\
Female & 41 & 75.9 \\
Total & 54 & 100.0
\end{tabular}

Tabel 2. Participant based on Age

\begin{tabular}{lll}
\hline Age & Amount & Percentage (\%) \\
\hline 19 years old & 4 & 7.4 \\
20 years old & 37 & 68.5 \\
21 years old & 10 & 18.5
\end{tabular}




$\begin{array}{lll}22 \text { years old } & 2 & 3.7 \\ >22 \text { years old } & 1 & 1.9 \\ \text { Total } & 54 & 100.0\end{array}$

Tabel 3. Participant based on Education

\begin{tabular}{lll}
\hline Education & Amount & Percentage (\%) \\
\hline Bachelor & 52 & 96.3 \\
Master & 1 & 1.9 \\
Other & 1 & 1.9 \\
Total & 54 & 100.00
\end{tabular}

Tabel 4. Participant based on Major

\begin{tabular}{lll}
\hline Major & Amount & Percentage (\%) \\
\hline Psychology & 53 & 98.1 \\
Other & 1 & 1.9 \\
Total & 54 & 100.0
\end{tabular}

Tabel 5. Participant based on Religion

\begin{tabular}{lll}
\hline Religion & Amount & Percentage (\%) \\
\hline Christiani & 18 & 33.3 \\
Catolic & 12 & 22.2 \\
Muslim & 14 & 25.9 \\
Buddhis & 7 & 13.0 \\
Hindu & 1 & 1.9 \\
No Religion & 2 & 3.7 \\
Total & 54 & 100.0
\end{tabular}

Spiritual well-being has a hypothetical mean of 3 . The total academic stress has an empirical mean of 3.670 ( $\mathrm{SD}=0.533$ ). The empirical mean value is greater than the hypothetical mean, meaning that the participants' spiritual well-being is high. Table 6 shows the empirical mean of spiritual well-being.

Table 6. Empirical Means of Spiritual Well-Being

\begin{tabular}{llll}
\hline Variabel & Hypothetical Mean & Empirical Mean & Meaning \\
\hline Spiritual Well-Being & 3 & 3.670 & High
\end{tabular}


Quality of life has a hypothetical mean of 3. The total quality of life has an empirical mean of 3.701 ( $S D=0.468)$. The empirical mean value is greater than the hypothetical mean, meaning that the participants' quality of life is high.

The general quality of life dimension has an empirical mean of 3.768 (SD=0.619), the dimension of domain 1 has an empirical mean of $3.748(\mathrm{SD}=0.577)$ domain 2 dimension has an empirical mean of $3.623(\mathrm{SD}=0.507)$, the dimension of domain 3 has an empirical mean of 3.623 ( $S D=0.573)$. the empirical mean value is greater than the hypothetical mean, meaning self-regulated learning on the self-efficacy, intrinsic value, cognitive strategy use, and self-regulation is high. Table 7 shows the empirical mean of each dimension and total quality of life.

Table 6. Empirical Means of Spiritual Well-Being

\begin{tabular}{llll}
\hline Dimension & Hypothetical Mean & Empirical Mean & Meaning \\
\hline Quality of Life & 3 & 3.768 & High \\
Quality of life in & 3 & 3.7481 & High \\
General & 3 & & \\
Physical & 3 & 3.748 & High \\
Psychological & 3 & 3.623 & High \\
Social Relation & 3 & 3.734 & High \\
Environmental & & 3.701 & High
\end{tabular}

Normality testing was carried out using the One-Sample Kolmogorov-Smirnov Test to determine the correlation technique that will be used. Spiritual well-being has a significance value of $p=0.269>0.05$, meaning that the data are normally distributed, QOL has a significance value of $\mathrm{p}=0.742>0.05$, meaning that the data is normally distributed. Based on the results the overall data is normally distributed because the variables has a significance value below 0.05 . Table 7 shows these findings.

Table 7. Normality Test

\begin{tabular}{llll}
\hline Variable & Shapiro-Wilk & Sig. (2 tailed) & Meaning \\
\hline Spiritual Well-Being & 1.001 & 0.269 & Normal \\
Quality of Life & 0.681 & 0.742 & Normal
\end{tabular}


With the data being normally distributed, the correlation is calculated using Pearson Correlation. The correlation between spiritual well-being and quality of life shows that there is a significant positive relationship based on the value of $r=0.471, p=0.000<$ 0.05. Table 8 shows these findings.

Table 8. Relationship Spiritual Well-Being and Quality of Life

\begin{tabular}{lll}
\hline Variable & $\begin{array}{l}\text { Correlation } \\
\text { Coefficient }(r)\end{array}$ & Sig. (2 tailed)
\end{tabular}

\begin{tabular}{lllll}
\hline Spiritual Well-Being & and & 0.471 & 0.000 & Significant \\
Quality of Life & & & & correlation
\end{tabular}

Based on the analysis of additional data through the processing of spiritual well-being differences test based on gender, Independent Sample T-Test was used. Results show the value of $p=0.297>0.05$, meaning that there are no significant differences in spiritual well-being based on gender. Female has a higher mean score (3.713) than male (3.534). As shown in Table 9.

Table 9. Spiritual Well-Being based on Gender

\begin{tabular}{llll}
\hline Gender & N & Mean Rank & Sig. (2 tailed) \\
\hline Male & 13 & 3.534 & 0.297 \\
Female & 41 & 3.713 &
\end{tabular}

Independent Sample T-Test was used in the processing of quality of life differences test based on gender, results show the value of $p=0.038<0.05$, meaning that there are significant differences in quality of life based on gender. Female has a higher mean score (3.788) than male (3.482). As shown in Table 10.

Table 10. Quality of Life based on Gender

\begin{tabular}{llll}
\hline Gender & $\mathbf{N}$ & Mean Rank & Sig. (2 tailed) \\
\hline Male & 13 & 3.482 & 0.038 \\
Female & 41 & 3.788 &
\end{tabular}


One-Way Anova was used in the processing of spiritual well-being differences test based on age, results show the value of $\mathrm{p}=0.716>0.05$, meaning that there are no significant differences in spiritual well-being based on age. As shown in Table 11.

Table 11. Spiritual Well-Being based on Age

\begin{tabular}{lll}
\hline Variabel & F & Sig. (2 tailed) \\
\hline Spiritual Well-Being & 0.528 & 0.716
\end{tabular}

One-Way Anova was used in the processing of quality of life differences test based on age, results show the value of $p=0.719>0.05$, meaning that there are no significant differences in quality of life based on age. As shown in Table 12.

Table 12. Quality of Life based on Age

\begin{tabular}{lll}
\hline Variabel & F & Sig. (2 tailed) \\
\hline Quality of Life & 0.523 & 0.719
\end{tabular}

One-Way Anova was used in the processing of spiritual well-being differences test based on education, results show the value of $p=0.441>0.05$, meaning that there are no significant differences in spiritual well-being based on education. As shown in Table 13.

Table 13. Spiritual Well-Being based on Education

\begin{tabular}{lll}
\hline Variabel & F & Sig. (2 tailed) \\
\hline Spiritual Well-Being & 0.833 & 0.441
\end{tabular}

One-Way Anova was used in the processing of quality of life differences test based on education, results show the value of $p=0.329>0.05$, meaning that there are no significant differences in quality of life based on education. As shown in Table 14.

Table 14. Quality of Life based on Education

\begin{tabular}{lll}
\hline Variabel & F & Sig. (2 tailed) \\
\hline Quality of Life & 1.136 & 0.329
\end{tabular}


One-Way Anova was used in the processing of spiritual well-being differences test based on major, results show the value of $p=0.370>0.05$, meaning that there are no significant differences in spiritual well-being based on major. As shown in Table 15.

Table 15. Spiritual Well-Being based on Major

\begin{tabular}{lll}
\hline Variabel & F & Sig. (2 tailed) \\
\hline Spiritual Well-Being & 0.819 & 0.370
\end{tabular}

One-Way Anova was used in the processing of quality ofe life differences test based on major, results show the value of $\mathrm{p}=0.943>0.05$, meaning that there are no significant differences in quality of life based on major. As shown in Table 16.

Table 16. Quality of Life based on Major

\begin{tabular}{lll}
\hline Variabel & F & Sig. (2 tailed) \\
\hline Quality of Life & 0.005 & 0.943
\end{tabular}

One-Way Anova was used in the processing of spiritual well-being differences test based on religion, results show the value of $p=0.838>0.05$, meaning that there are no significant differences in spiritual well-being based on religion. As shown in Table 17.

Table 17. Spiritual Well-Being based on Religion

\begin{tabular}{lll}
\hline Variabel & F & Sig. (2 tailed) \\
\hline Spiritual Well-Being & 0.412 & 0.838
\end{tabular}

One-Way Anova was used in the processing of quality of life differences test based on religion, results show the value of $p=0.812>0.05$, meaning that there are no significant differences in quality of life based on religion. As shown in Table 18.

Table 18. Quality of Life based on Religion

\begin{tabular}{lll}
\hline Variabel & F & Sig. (2 tailed) \\
\hline Quality of Life & 0.449 & 0.812
\end{tabular}


Different tests were also conducted on the dimensions of quality of life. Independent Sample T-Test was used in the processing of dimensions quality of life differences test based on gender, The results show that on the dimension of quality of life, in general, the value of $p=0.996>0.05$ meaning that there are no significant differences in dimension quality of life in general based on gender. On the physical dimension the value of $p=0.006<0.05$, meaning that there are significant differences in physical dimension based on gender. On the domain 2 the value of $p=0.128>0.05$, meaning that there are no significant differences in domain 2 based on gender. On the domain 3 the value of $p=0.030<0.05$, meaning that there are significant differences in domain 3 based on gender. On the domain 4 the value of $p=0.036<0.05$, meaning that there are significant differences in domain 4 based on gender. As shown in Table 19.

Table 19. Dimensions Quality of Life based on Gender

\begin{tabular}{lll}
\hline Dimensions & t & Sig. (2 tailed) \\
\hline Quality of Life in General & 0.005 & 0.996 \\
Physical & -2.897 & 0.006 \\
Psychological & -1.548 & 0.128 \\
Social Relation & -2.236 & 0.030 \\
Environmental & -2.150 & 0.036
\end{tabular}

One-Way Anova was used in the processing of dimensions quality of life differences test based on age. The results show that on the dimension of quality of life, in general, the value of $p=0.910>0.05$ meaning that there are no significant differences in dimension quality of life in general based on age. On the physical dimension the value of $p=0.292$ $>0.05$, meaning that there are no significant differences in physical dimension based on age. On the domain 2 the value of $p=0.858>0.05$, meaning that there are no significant differences in domain 2 based on age. On the domain 3 the value of $p=0.510>0.05$, meaning that there are no significant differences in domain 3 based on age. On the domain 4 the value of $\mathrm{p}=0.609>0.05$, meaning that there are no significant differences in domain 4 based on age. As shown in Table 20. 
Table 20. Dimensions Quality of Life based on Age

\begin{tabular}{lll}
\hline Dimensions & F & Sig. (2 tailed) \\
\hline Quality of Life in General & 0.247 & 0.910 \\
Physical & 1.276 & 0.292 \\
Psychological & 0.328 & 0.858 \\
Social Relation & 0.835 & 0.510 \\
Environmental & 0.680 & 0.609
\end{tabular}

One-Way Anova was used in the processing of dimensions quality of life differences test based on education. The results show that on the dimension of quality of life, in general, the value of $\mathrm{p}=0.122>0.05$ meaning that there are no significant differences in dimension quality of life in general based on education. On the physical dimension the value of $p=0.587>0.05$, meaning that there are no significant differences in physical dimension based on education. On the domain 2 the value of $p=0.279>0.05$, meaning that there are no significant differences in domain 2 based on education. On the domain 3 the value of $\mathrm{p}=0.461>0.05$, meaning that there are no significant differences in domain 3 based on education. On the domain 4 the value of $p=0.500>0.05$, meaning that there are no significant differences in domain 4 based on education. As shown in Table 21.

Table 21. Dimensions Quality of Life based on Education

\begin{tabular}{lll}
\hline Dimensions & F & Sig. (2 tailed) \\
\hline Quality of Life in General & 2.192 & 0.122 \\
Physical & 0.538 & 0.587 \\
Psychological & 1.310 & 0.279 \\
Social Relation & 0.785 & 0.461 \\
Environmental & 0.702 & 0.500
\end{tabular}

One-Way Anova was used in the processing of dimensions quality of life differences test based on major. The results show that on the dimension of quality of life, in general, the value of $p=0.710>0.05$ meaning that there are no significant differences in dimension quality of life in general based on major. On the physical dimension the value of $\mathrm{p}=$ 
$0.343>0.05$, meaning that there are no significant differences in physical dimension based on major. On the domain 2 the value of $p=0.460>0.05$, meaning that there are no significant differences in domain 2 based on major. On the domain 3 the value of $p=$ $0.485>0.05$, meaning that there are no significant differences in domain 3 based on major. On the domain 4 the value of $\mathrm{p}=0.770>0.05$, meaning that there are no significant differences in domain 4 based on major. As shown in Table 22.

Table 22. Dimensions Quality of Life based on Major

\begin{tabular}{lll}
\hline Dimensions & F & Sig. (2 tailed) \\
\hline Quality of Life in General & 0.140 & 0.710 \\
Physical & 0.915 & 0.343 \\
Psychological & 0.555 & 0.460 \\
Social Relation & 0.494 & 0.485 \\
Environmental & 0.086 & 0.770
\end{tabular}

One-Way Anova was used in the processing of dimensions quality of life differences test based on religion. The results show that on the dimension of quality of life, in general, the value of $\mathrm{p}=0.630>0.05$ meaning that there are no significant differences in dimension quality of life in general based on religion. On the physical dimension the value of $\mathrm{p}=0.936>0.05$, meaning that there are no significant differences in physical dimension based on religion. On the domain 2 the value of $p=0.802>0.05$, meaning that there are no significant differences in domain 2 based on religion. On the domain 3 the value of $\mathrm{p}=0.946>0.05$, meaning that there are no significant differences in domain 3 based on religion. On the domain 4 the value of $p=0.464>0.05$, meaning that there are no significant differences in domain 4 based on religion. As shown in Table 23.

Table 23. Dimensions Quality of Life based on Religion

\begin{tabular}{lll}
\hline Dimensions & F & Sig. (2 tailed) \\
\hline Quality of Life in General & 0.695 & 0.630 \\
Physical & 0.254 & 0.936 \\
Psychological & 0.463 & 0.802 \\
Social Relation & 0.233 & 0.946 \\
Environmental & 0.940 & 0.464
\end{tabular}




\section{Discussion}

Based on the research results, it is known that there is a positive relationship between spiritual well-being and quality of life. This shows that the higher a person's spiritual well-being, the higher the quality of one's life. Vice versa, the lower one's spiritual well-being, the lower one's quality of life. This is in line with research by Buulolo ${ }^{14}$ which shows that there is a positive relationship between spiritual well-being and quality of life in students. A person who has good spiritual well-being will have a good relationship with himself, nature and God. Therefore, their quality of life will be good. She will accept herself as she is, take care of herself and have a good relationship with the people around her. His life will be peaceful. In line with Larasati's statement in Anderson, Loekmono and Setiawan ${ }^{17}$ which states that a person who has a positive quality of life will be seen from the physical aspect of how he/she maintains his/her health, from the psychological aspect, a person will try to relieve his emotions so that he does not get angry easily, if viewed from the aspect of social relations, a person will have good relationship with his friends and with the environment around him. A person will be able to recognize himself, and be able to adapt to any conditions, have compassion for others and be able to develop an attitude of empathy and feel the suffering of others. ${ }^{18}$

A person's quality of life and religiosity can also affect a person's subjective wellbeing. This is in line with research by Anderson, Loekmono and Setiawan ${ }^{17}$ which shows that quality of life and religiosity simultaneously have a significant effect on the formation of subjective well-being because when a person has a good quality of life such as a pleasant feeling and has health, psychological support, social support and the place where they live. staying will create good subjective well-being for that person. ${ }^{19}$

\footnotetext{
${ }^{17}$ Anderson, Lindin, JT Lobby Loekmono, and Adi Setiawan. "Pengaruh Quality Of Life Dan Religiusitas Secara Simultan Terhadap Subjective Well Being Mahasiswa Teologi." Evangelikal: Jurnal Teologi Injili dan Pembinaan Warga Jemaat 4.1 (2020): 14-27. https://doi.org/10.46445/ejti.v4i1.194.

${ }^{18}$ Pamela Hendra Heng, Desiree Gracia Nelwan, Septi Lathiifah. "Overview Of Psychological WellBeing And Forgiveness Of Christian Youth In North Sumatera." MAHABBAH: Journal of Religion and Education, Vol.2. No.2 (2021): 93-111. https://doi.org/10.47135/mahabbah.v2i2.28.

${ }^{19}$ Comp. Yoseti Gulo \& Widjaja Sugiri. 2020. “Pengaruh Guru Pendidikan Agama Kristen Terhadap Pelayanan Remaja Dalam Konteks Gereja Di Indonesia (The Influence Of Christian Religion Education Toward Teenagers Services In The Context Of Churches In Indonesia)". QUAERENS: Journal of Theology and Christianity Studies, Vol.2, No.2: 86-101. https://doi.org/10.46362/quaerens.v2i2.22; Imron Widjaja, Bobby Kurnia Putrawan, \& Hengki Wijaya. "Manajemen Pendidikan Agama Kristen Melalui Pelayanan Penggembalaan Dalam Kelompok Sel." EDUKASI: Jurnal Penelitian Pendidikan Agama dan Keagamaan, Vol.18, No.2 (2020): 159-170. DOI : https://doi.org/10.32729/edukasi.v18i2.689.
} 
In this research, it is known that the level of spiritual well-being and quality of life of the participants are in the high category. This is in line with Buulolo ${ }^{14}$ research which shows that the level of spiritual well-being and quality of life in university students is in the high category.

On the results of additional data analysis, a different test was performed. In the spiritual well-being difference test, there were no differences in terms of gender, age, education, majors and religion. Meanwhile, in the different quality of life tests, differences were found based on age. Different tests were also carried out on the quality of life dimension. There are differences in the physical, social relations, and environmental dimensions in terms of gender.

This research has limitations, including the research was conducted during the COVID-19 pandemic, this causes the distribution of questionnaires and personal communication to be done online. Therefore, the researcher could not make direct observations to the participants. In addition, the number of participants in this study only amounted to 54 people, which is still a small number to be used as a research sample. Suggestions for further research is to increase the number of research participants so that they are more diverse. Further research can also add other variables to be used as mediators between spiritual well-being and quality of life.

\section{CONCLUSION}

Based on the results of the study, it is known that there is a positive relationship between spiritual well-being and quality of life in students during the COVID-19 pandemic. Spiritual well-being and quality of life of students are in the high category. In the different test, it is known that there are differences in the quality of life in terms of age. Different tests were also carried out on the dimensions of quality of life, it was found that there were differences in the physical, social relations, and environmental dimensions in terms of gender.

\section{AKNOWLEDGEMENTS}

The author would like to express deepest appreciation to all the participants involved during data collection for this study. 


\section{REFERENCE}

Ali, J., Marhemat, F., Sara, J., \& Hamid, H. “The Relationship between Spiritual Well-Being and Quality of Life among Elderly People". Holistic Nursing Practice (2015). https://doi.org/10.1097/HNP.0000000000000081

Anderson, Lindin, JT Lobby Loekmono, and Adi Setiawan. "Pengaruh Quality Of Life Dan Religiusitas Secara Simultan Terhadap Subjective Well Being Mahasiswa Teologi." Evangelikal: Jurnal Teologi Injili dan Pembinaan Warga Jemaat Vol.4, No.1 (2020): 14-27. https://doi.org/10.46445/ejti.v4i1.194.

Bhandari, S., Shaktawat, A. S., Patel, B., Dube, A., Kakkar, S., Tak, A., Gupta, J., \& Rankawat, G. "The sequel to COVID-19: the antithesis to life". Journal of Ideas in Health (2020). https://doi.org/10.47108/jidhealth.vol3.issspecial1.69.

Buulolo, Delviana. "Quality Of Life Ditinjau Dari Spiritual Well-Being Pada Mahasiswa Kependetaan Di Sekolah Tinggi Theologia Injili Indonesia Medan-Sumatera Utara." Jurnal Psikologi Universitas HKBP Nommensen Vol.6, No.1 (2019): 21-27.

Dong, Han., Zhang, Jun., \& Cirillo, Cinzia. “Exploring, understanding, and modeling the reciprocal relation between leisure and subjective well-being". Transportation Research Part A: Policy and Practice (2019). 813-824. https://doi.org/10.1016/j.tra.2019.10.009.

Fisher, John. "Development and application of a spiritual well-being questionnaire called SHALOM". Religions (2010). https://doi.org/10.3390/rel1010105.

Fisher, John. "The four domains model: Connecting spirituality, health and well-being". Religions (2011). https://doi.org/10.3390/rel2010017.

Gulo, Yoseti, and Widjaja Sugiri. 2020. "Pengaruh Guru Pendidikan Agama Kristen Terhadap Pelayanan Remaja Dalam Konteks Gereja Di Indonesia (The Influence Of Christian Religion Education Toward Teenagers Services In The Context of Churches In Indonesia)". QUAERENS: Journal of Theology and Christianity Studies, Vol.2, No.2: 86-101. https://doi.org/10.46362/quaerens.v2i2.22.

Gomez, Rapson., \& Fisher, John. “Spiritual Well-Being Questionnaire[Database record]”. Retrieved from PsycTESTS (2003). Doi: 10.1037/t12442-000.

Heng, Pamela Hendra, Desiree Gracia Nelwan, \& Septi Lathiifah. "Overview Of Psychological Well-Being And Forgiveness Of Christian Youth In North Sumatera." MAHABBAH: Journal of Religion and Education, Vol.2. No.2 (2021): 93-111. https://doi.org/10.47135/mahabbah.v2i2.28. 
Pirasteh Motlagh, A. A., Nikmanesh, Z., Liaghat, E., \& Hematian, M. "The role of spirituality in feelings of suffering and quality of life in self- introduced addicts". Journal of Research and Health (2019). https://doi.org/10.29252/jrh.9.2.104

Purba F. D, Hunfeld J. A. M., Iskandarsyah A., Fitriana T. S., Sadarjoen, S. S., Passchier J., \& Busschbach, J. V. "Quality of life of the Indonesian general population: Test-retest reliability and population norms of the EQ-5D-5L and WHOQOL-BREF". PLOS ONE 13(5) (2018). https://doi.org/10.1371/journal.pone.0197098.

The WHOQOL Group. The World Health Organization quality of life assessment (WHOQOL): Position paper from the World Health Organization. Social Science \& Medicine, Vol.41, No.10 (1995): 1403-1409.

The WHOQOL Group. WHOQOL-BREF: Introduction, administration, scoring, and generic version of the assessment. Geneva: World Health Organization, 1996

Tonon, G. Relevance of the use of qualitative methods in the study of quality of life. in G. Tonon (Eds.), Qualitative studies in quality of life: Methodology and practice. (pp. 5). Switzerland: Springer, 2015.

Tumanggor, Raja Oloan \& Dariyo, Agoes. "Pelatihan peningkatan spiritual well-being bagi lansia di gereja HKBP Cengkareng Jakarta Barat. Sanapenmas (2019). 394-400. Widjaja, I., Bobby Kurnia Putrawan, \& Hengki Wijaya. "Manajemen Pendidikan Agama Kristen Melalui Pelayanan Penggembalaan Dalam Kelompok Sel." EDUKASI: Jurnal Penelitian Pendidikan Agama dan Keagamaan, Vol.18, No.2 (2020): 159-170. https://doi.org/10.32729/edukasi.v18i2.689.

World Health Organization. "Mental Health and Psychosocial Considerations During COVID-19 Outbreak". World Health Organization (2020). 